\title{
Music Iconography, Opera, Gender and Cultural Revolution - The Case Study of the Kwok On Collection (Portugal)
}

\author{
Luzia Aurora RochA \\ NOVA FCSH/CESEM, Colégio Almada Negreiros, \\ Campus de Campolide, 1099-085 Lisboa, Portugal \\ E-mail: luzia.rocha@fcsh.unl.pt
}

(Received: March 2018; accepted: June 2018)

\begin{abstract}
This study aims to revisit the creation of opera, symphonic versions of opera and ballet (yangbanxi) during the period of the Cultural Revolution of Mao's China. Beginning with the Kwok Collection (Fundação Oriente, Portugal), I aim to establish a new vision of the yangbanxi (production and reception) by means of an analysis of sources with musical iconography. The focus of the study is on questions of gender and the way in which the feminine was an indispensable tool for the construction and dissemination of the idea of a new nation-state. This study thus aims to make a new contribution to the area, showing how the construction of new opera heroines, communist and of the proletariat, is built on the image of the first "heroine-villain" constructed by the regime, Jiang Qing, the fourth wife of Mao Zedong. The title chosen demonstrates the paradox of the importance of woman in opera and in politics at a time when the only image to be left to posterity was that of a dominant male hero, Mao Zedong.
\end{abstract}

Keywords: cultural revolution, opera, gender, China, musical iconography

\section{Introduction}

The Kwok On Collection results from the 1971 donation by Mr. Kwok On of a set of Cantonese puppets, musical instruments, books and assorted objects in favour of Jacques Pimpaneau. This donation became the original core collection of an association/museum founded in Paris, the Kwok On Museum, by Jacques Pimpaneau who then immediately set about expanding the collection. The collection covers a geographic area extending from Turkey right across to Japan and in 1999, the year it was donated to the Orient Foundation (Lisbon, Portugal), totalled over 
10,000 pieces. The collection was originally restricted to the field of cultural ethnology and broadly focused on the range of theatrical forms to be found in Asia. Subsequently, the scope was broadened to take in all genres that convey myths and cultural features common to the major Asian civilizations. Hence, it also includes every aspect relating to the performance arts: costumes, masks, musical instruments, props, shadow and puppet theatres given that in Asia they perform just as any actor-based theatre and occasionally of a greater religious significance.

In the year 2016, the Orient Foundation organized "The Chinese Opera" exhibition that included some 280 objects sourced from the Kwok On Collection, one of the core collections, considered the top of its genre at a European scale, including items of a remarkable quality and great impact. The exhibition surprised for both the quality and the quantity of the pieces on display, but the Cultural Revolution nucleus was a surprise for both academics and visitors for the quality and interest of the selected objects. These article addresses those particular objects, studied and analysed from a music iconography point of view and taking into consideration gender questions.

\section{Historical background}

After the foundation of the People's Republic of China, on 1 October 1949, a government designed on the Soviet model was created. At the beginning, this government recognized the existence of other small parties ${ }^{1}$ and of four social classes: workers, farmers, small-scale and large-scale capitalists, all regulated by a "democratic dictatorship." The executive, legislative and judicial powers were in the hands of the Central Government, which had 71 members and Mao Zedong (1893-1976) as president. ${ }^{2}$ The country remained subdivided into provinces and districts. The constitution established two types of citizens: men and women of over eighteen years of age were full citizens; those considered to be landowners/landlords and as counter-revolutionaries were simply excluded. The Chinese Communist Party had, at thus time, some 4-5 million members.

The "Great Proletarian Cultural Revolution" officially began on 18 April $1966 .{ }^{3}$ The term "cultural" should not be taken literally since one of the first measures to be implemented was precisely the closing of all universities and the majority of schools, at a time when China had greater, urgent, need of men for military

1. Which had, nevertheless, no relevance or role at all in political life.

2. See Pierre Fromentin, Mao Tsétung: La Dragon Rouge (Paris: Éditions Médicis, 1949).

3. Provoked by the confrontation of Mao Zedong and Liu Shaoqi (1898-1969), one of the main organizers of the Chinese Communist Party. Appointed President of the People's Republic (1959) and recognized as Mao's heir, Liu argued with him before the period of the Cultural Revolution, which led to his expulsion from the Party. See Roderik MacFarquhar, The Origins of the Cultural Revolution (London: Oxford University Press, 1983). 
training. ${ }^{4}$ One of the tensest periods was the autumn of 1967 , when some schools reopened, but the struggles, especially in provincial centres, continued to the end of 1968.

At that time Mao had complete control of the nation and had once more won a decisive victory against Liu Shaoqi. ${ }^{5}$ In favour of Mao were Zhu De, the man who created the Chinese Red Army (the People's Liberation Army), Lin Biao, ${ }^{6}$ Ch'en Boda $^{7}$ and Jiang Qing. ${ }^{8}$ Jiang was a film actress (under the name of Lan Ping) before the revolutionary period. After a life full of changes, she felt compelled to leave Shanghai and the world of the film industry, joining a communist camp in Yenan, where she became the lover and, later, wife of Mao.

The social changes that occurred during this period were various, such as the control of the birth rate and the announcement of the eradication of infectious diseases (such as syphilis, for example). The change in the social role of women was important. Women's “emancipation” by the marriage law of April 1950 made them "equal" to their spouses, at least theoretically. Essentially, a woman came to have the same right to work as her husband, in the sense of being able to have a full-time job outside the home (to which would be added housework and the care of the children). Divorces were easier to obtain for men and the argument of political incompatibility as a cause of separation became possible. This legal change in the status of women, even if theoretical, would be decisive for the change that would later occur in their role in society, whether on the operatic stage or as an instrument of propaganda ${ }^{9}$ for the regime. The socialist system would transform the image of woman in drastic fashion. In a kind of ghost of the old social system - a patriarchal culture with symptomatic repression of women - it became the symbol of the nation, with the occurrence of a "nationalization" of the female gender.

\section{The creation of model works (yangbanxi)}

In China, the term "revolutionary opera [or work]" refers to model works (or yangbanxi) - opera, ballet and symphony - whose construction is attributed to the period of the Cultural Revolution (1966-1976) and to Jiang Qing. However, these

4. Wolfram Eberhard, A History of China (Berkeley: University of California Press, 1977).

5. From this point Liu Shaoqi disappeared from the political scene.

6. He became the first vice-president of the Central Committee, that is, the second most powerful of the regime and Mao's designated successor.

7. Member of the Chinese Communist Party and Mao's secretary. He was one of the most powerful members during the Cultural Revolution.

8. Jiang Qing was her "revolutionary name," a pseudonym. Born Li Shumeng (1914-1991), she adopted various names during the course of her life.

9. See Arnold Perris, "Music as Propaganda at the Command Doctrine in the People's Republic of China," Ethnomusicology 27/1 (January 1983), 1-28; and Barbara Mittler, "Popular Propaganda? Art and Culture in Revolutionary China," Proceedings of the American Philosophical Society, Philadelphia 152/4 (December 2008), 466-489. 
model works have their roots in earlier times. That is, they are the result of events and reflections which had already begun long before the period of the Cultural Revolution. Indeed, the yangbanxi were far less a product of the Cultural Revolution that they may appear to be:

When did China's Cultural Revolution begin? ... seen from the perspective of cultural production, the Cultural Revolution originated some time in the late nineteenth century. ${ }^{10}$

They are, rather, based on much of the popular history of China, and also on a Western music-dramatic legacy:

... some traditional music was, in fact, redeveloped rather than destroyed during the Cultural Revolution. ${ }^{11}$

Everyone of the model works, be it an opera, a ballet, or a piece of symphonic or piano music, makes extensive use of a number of musico-semantic signs derived from the repertoire of foreign classical and romantic music. ${ }^{12}$

These works were considered "revolutionary" and "modern" in their themes and music, in comparison with the operas of the established traditional repertoire. The official versions of these productions were those of the Peking Opera Company or the Peking Opera Company of Shanghai, later being adapted by opera companies from other regions. Many of these new productions were also adapted for cinema.

Of these productions (eighteen in total), eight straightaway entered the canon. In the place of the traditional characters (emperors, kings, generals, administrators, maidens and so forth) of the traditional repertoire of the Peking opera (banished because it was considered feudalist and bourgeois), there appeared new heroes from the proletariat who fought against the enemies of the Communist Party and the nation, recounting episodes from more recent Chinese history. These works glorified the bravery of the people, of the common citizen, and showed Mao Zedong as a central figure in the victory of socialism in China. ${ }^{13}$ Though they were produced as operas (stage productions), these were model works soon

10. Barbara Mittler, A Continuous Revolution: Making Sense of Cultural Revolution Culture (Cambridge: Harvard University Press, 2012), 39.

11. Mittler, A Continuous Revolution, 39.

12. Ibid., 68.

13. Curiously, Mao's hate for the old emperors and the old Chinese social system did not prevent him from becoming a similar figure. At the opera, Mao was greeted and his portrait hung on stage. He took on the role of the "sun of the nation" - an image of which appeared on the stage, as a symbol of Mao - a godlike figure, as inspiring, of praise as any emperor of the old regime, or more so. He is the Chinese sun that had risen in the East according to the words of the famous song "Red Is the East." See also Harrison E. Salisbury, The New Emperors. Mao and Deng: A Dual Biography (London: Harper Collins Publishers, 1993). 
disseminated in other media: LPs, comics, posters, postcards, stamps, etc. They were broadcast on radio or through loudspeakers in schools, factories, fields, performed by groups formed especially for this purpose. These eight model operas dominated the stages of the entire country during this period. ${ }^{14}$

Between 1949 and 1955, the Chinese government formed committees and agencies, both in Peking and in other important centres in the country, in order to carry out a reform of Chinese opera. Thus, more traditional works were revised, principally in terms of their texts, and new operas were composed with contemporary and revolutionary themes. Mao Zedong wanted the operas to create new models of the hero of the proletariat intended for the service of the masses. The Party saw opera - a popular genre with a great number of adherents - as a powerful instrument for the instruction and control of the masses. In his lecture given at the Yenan Forum, on the theme of literature and art, Mao indicates that literature and art are for the masses and for the people and must be for their use:

All our literature and art are for the masses of the people, and in the first place for the workers, peasants and soldiers; they are created for the workers, peasants and soldiers and are for their use. ${ }^{15}$

He also indicates, in a letter to the Peking Opera Theatre of Yenan, that the "old opera" was divorced from the people, requiring the creation of new pieces, connected to the "historical truth" of the present:

History is made by the people, yet old opera (and all old literature and art, which are divorced from the people) presents the people as though they were dirt, and the stage is dominated by lords and ladies and their pampered sons and daughters. Now you have reversed this reversal of history and restored historical truth, and thus a new life is opening up for the old opera. That is why this merits congratulations. The initiative you have taken marks an epoch-making beginning in the revolutionization of the old opera. I am very happy at the thought of this. I hope you will write more plays and give more performances, and so help make this practice a common one which will prevail throughout the country. ${ }^{16}$

14. Barbara Mittler, "Eight Stage Works for 800 Million People: The Great Proletarian Cultural Revolution in Music - A View from Revolutionary Opera," The Opera Quarterly 26/2 (September 2010), 377-401.

15. Quotation on the back cover of Jiang Qing, On the Revolution of Peking Opera (Peking: Foreign Languages Press, 1968).

16. Both quotations introduce the publication which contains Jiang Qing's speech and various texts in appendix, all dealing with the revolution and reform of the Peking Opera (see previous footnote). 


\section{Jiang Qing - the female political giant and the first "heroine-villain" of the new Chinese opera}

In the process of the production of new operatic models and the reformulation of the old, one might think that Jiang Qing (1914-1991) was merely a spokesperson for Mao's ideas. But this would be extremely reductive. Mao's wife spoke in clearer, pragmatic terms and with very concrete ideas. To Mao's criticism in July 1975 that "there are too few model works," Jiang Qing is said to have replied: "There are people who say that there are too few model works, that there are just eight, but it is not true! Already now they are eighteen."17

Jiang was the first of the new opera heroines. She was the model for the models presented on stage. Her own life could have been one of the new plots for a yangbanxi. The course of Jiang Qing's life was marked by a number of vicissitudes: the separation of her parents, when she was very young, poverty and the attendant difficulties, a love affair during her adolescence with the headmaster of the school she attended. In addition, she always suffered from the relegation to the background of her professional life, which contributed to a certain accumulation of resentment towards life. In her career as an actress it is possible to see, through the testimony of her colleagues, that she constantly rebelled against the insignificance and secondariness of the roles she was given by the film industry..$^{18}$ The beginning of her relationship with Mao Zedong was also made difficult by Ho Tze-chen, who was married to Mao at this time. During this phase Jiang Qing was related to the background, designated for domestic life and with no involvement with active political life. Her entrance into Chinese political and cultural life goes back to the 1950s, when she was appointed a member of the Central Committee ${ }^{19}$ for the film industry, an integral part of the Ministry of Culture. This was merely an honorary position, but Jiang took it up with enthusiasm, giving regular lectures at a number of events. In 1964 she was elected delegate. This was also an honorary position, but once more Jiang participated actively in her tasks. She was a leader of the Cultural Revolution. With the power she attained within this movement, Jiang subjugated and severely punished those who opposed her, including famous singers/actors, producers, conductors, writers and even other politicians. It is possible that this was her revenge on the world of culture, a world that punished her and in which her expectations of a career were completely frustrated and annihilated (Figure 1). ${ }^{20}$

17. Mittler, A Continuous Revolution, 46.

18. Hao-Jan Chu, "Mao's Wife - Chiang Ch'ing," The China Quarterly, no. 31 (July-September 1967), $148-150$.

19. S. a., Central Committee of the Chinese Communist Party Concerning the Great Proletarian Cultural Revolution (Peking: Foreign Languages Press, 1966).

20. The photograph reproduced in this propaganda magazine, taken on 1 July 1968, shows a very important moment in the Cultural Revolution. The caption reads: "Our great leader Mao Zedong and his close 
FIGURE 1 Mao Zedong and Jiang Qing with the cast of the operas Red Lantern and Shachiapang holding the little red book (detail). Propaganda magazine, Kwok On Collection, Fundação Oriente. (C) Author's photo

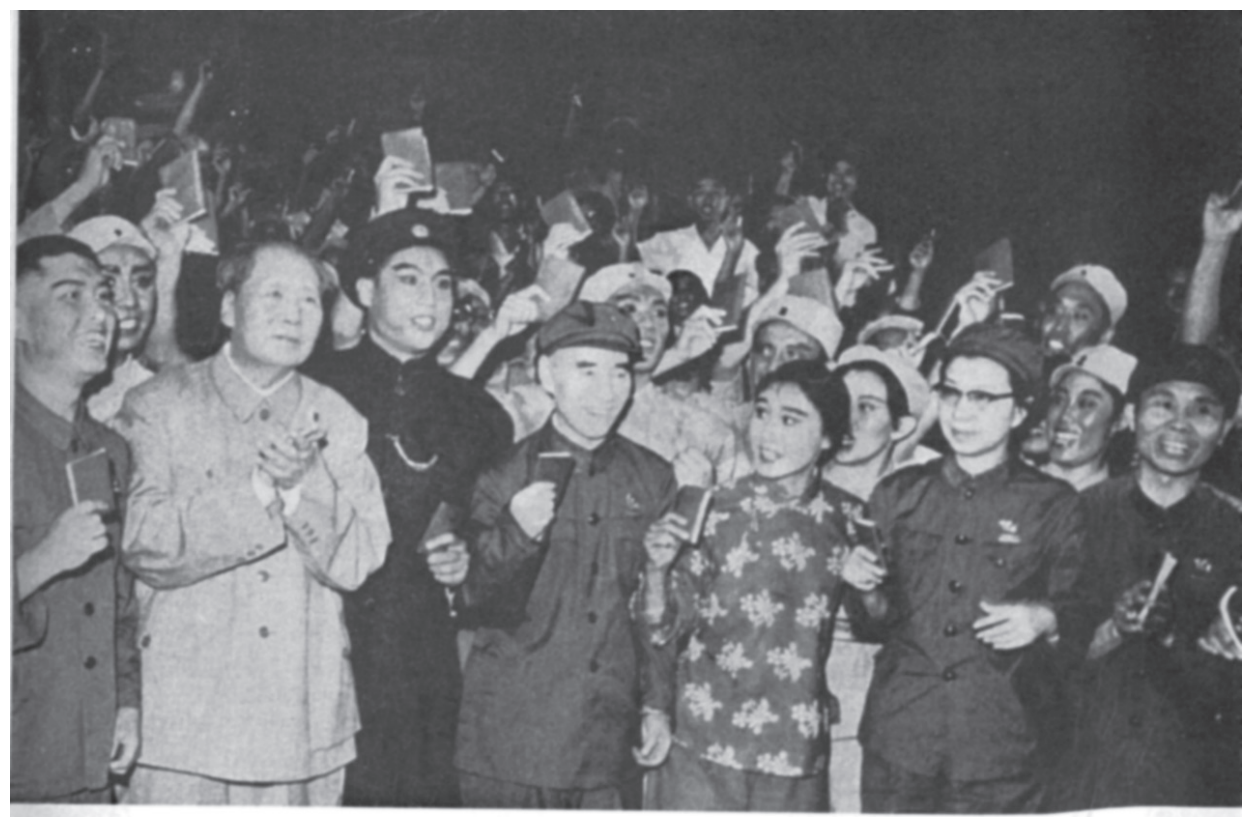

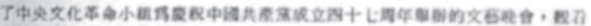
RHA

From her experience as an actress and the years in which she was part of the world of the arts there resulted a deeper knowledge of the world of artistic production. From her experience of life came all of her inflexibility and ambition. The ambition of being someone she had never been. Of finally coming out from the shadow and taking on, in real life, the leading role that she had never had in the cinema.

In Jiang Qing's speech given in July $1964,{ }^{21}$ was traced the path for the practical application of Mao's thought. With extremely clear and well-organized ideas,

companion in the struggle, Vice-President Lin Biao, on $1 \mathrm{July,} \mathrm{attended} \mathrm{the} \mathrm{festival} \mathrm{in} \mathrm{celebration} \mathrm{of} \mathrm{the}$ 47th anniversary of the foundation of the Chinese Communist Party. They heard a performance of The Red Lantern, accompanied on piano, as well as the symphonic version of the opera Shachiapang. At the end of the performance, President Mao and Vice-President Li Biao, as well as Zhou Enlai, Chen Boda, Kang Sheng and Jiang Qing, mounted the stage for a group photograph." (From a free translation to Portuguese, Professor Weimin Zhang, Fundação Oriente). From right to left in the photograph, in the front row, it is possible to identify: Chen Boda, Jiang Qing (in military uniform), Liu Changyu (the character Tiumei in the opera The Red Lantern), Lin Biao (in military uniform), Qian Haoliang (the character Li Yuhe in the opera The Red Lantern), Mao Zedong and the favourite pianist of the regime and the "Gang of Four," Yin Chengzong, author and performer of the piano version of The Red Lantern. The photograph reproduced in the magazine is larger than the fragment given here, it being also possible to see, in military uniform, Zhou Enlai and Kang Sheng.

21. At the Forum of the workers of the Theatre who took part in the Peking Opera Festival on contemporary themes. 
she was the main responsible for determining the path for the creation of contemporary opera and for the reform of the old. ${ }^{22}$ Her speech called for unity and collective participation. But, in reality, Jiang never left room for anybody else's opinions or contributions. Such a premise is illusory, used to bring together the energies of the agents necessary to the process she outlined. The first part of her speech began with an introduction to Mao's thought (almost a quotation of the speech at the Yenan Forum):

It is inconceivable that, in our socialist country led by the Communist Party, the dominant position on the stage is not occupied by the workers, peasants and soldiers, who are the real creators of history and the true masters of our country. ${ }^{23}$

But Jiang Qing also added a strategic politico-economic vision for the efficacious use of the arts, affirming, during the course of the speech, that "We should create literature and art which protect our socialist economic base." 24

The creation of model operas on revolutionary themes sought to be a mirror of the daily life of the last fifteen years (since the foundation of the People's Republic of China). It also sought the creation of images and models of contemporary revolutionary heroes. Thus, special attention was given to the composition of new repertoire and to creative writing, since the new pieces would be the basis of theatrical production. The writing of operas would be based on a kind of "Social Holy Trinity," composed by the political leaders, the writers and the masses, each with a well-defined and ordered function in a production line. Firstly, the leadership would establish the terms (always related to the contemporary world and to the Party); secondly, the writers had experience in the field, in order to have the necessary understanding of the life of the people and an exact idea of reality ${ }^{25}$ (it is at this point that contact with the masses); thirdly, the operas were, finally, produced. The second way of securing good repertoire would be through the above-mentioned adaptation. Firstly, there would be a careful choice of the operas to be reformulated, in order to check whether they were politically pertinent. Then a careful analysis of the original would be made. The adaptations should emphasize points of interest and remedy the designated "negative" or inconvenient points.

Jiang Qing was also careful to give clear and quite specific instructions, intended for the productions of the Peking Opera in particular. It was not intended to

22. Regarding this specific event, Mittler refers: "In order to achieve this goal, Mao demanded a more rigid policy of destruction of the old in order to construct a new revolutionary and national art. Henceforth, his wife Jiang Qing began her crusade to dominate the artistic world in China". Mittler, A Continuous Revolution, 79.

23. Qing, On the Revolution of Peking Opera, 1.

24. Ibid., 1.

25. Even taking part in military operations, the capture of enemy spies, etc. 
lose its character, but rather to maintain the characteristics of its singing, melody, acrobatics, while not compromising with the demands of the singers:

In adapting for Peking opera attention must be paid to two aspects: on the one hand, the adaptations must be in keeping with the characteristics of Peking opera, having singing and acrobatics, and words must fit the melodies in Peking opera singing. Otherwise the performers will not be able to sing. On the other hand excessive compromises should not be made with the performers. ${ }^{26}$

Mittler refers:

In constructing the "new system" of revolutionary opera, Jiang Qing and her teams of composers, performers and musicians drew on the old features from Beijing Opera, adding to them elements from spoken drama and from foreign operatic, ballet and symphonic traditions, especially those classic and romantic. They added stage props and settings, and they produced film versions of the operas, a practice that again introduced new artistic practices and stylistic elements to the original art form. ${ }^{27}$

Further, warnings were given regarding the construction of new characters. Given the traditional nature of the repertoire, which portrays the old noble and bourgeois social classes, Jiang Qing catalogued these characters as "negative." The dichotomy and polarization of the "positive and the "negative" was always present. The rule employed was quite simple: to create and emphasize everything that is "positive" (i. e., useful for the regime) and to eliminate or move to the background everything that is "negative." All of this was arranged in accordance with the theory of "Three Prominences", ${ }^{28}$ which postulates that (1) positive characters must be given prominence over all other characters, (2) heroic characters must be given prominence over positive ones, (3) among the heroic figures, prominence must be given to the main hero.

Qing also appeared in the struggle against the concept imposed by those who opposed her within the Peking Opera, that of "neutral music." For them, the music of the opera would be "neutral" in the sense that it could characterize, indiscriminately, any kind of character. That is, the music that characterized an emperor would also be effective in characterizing a soldier. Given that the philosophy of the Party was based on the distinction between "positive" characters (heroes of the proletariat) and "negative" characters (the old characters linked to the bourgeoisie and

26. Qing, On the Revolution of Peking Opera, 5.

27. Mittler, A Continuous Revolution, 90.

28. Ibid., 84; and Paul Clark, The Chinese Cultural Revolutionary Opera: A History (Cambridge \& New York: Cambridge University Press, 2008). 
the nobility), she fiercely opposed this idea of "neutral music." She considered that a particular music had a particular character that linked it to a specific social class. ${ }^{29}$

Eight yangbanxi, or model works (more specifically six operas and two ballets), were produced during the first three years of the period of the Cultural Revolution (Table 1). ${ }^{30}$

TABLE 1 List of the eight main yangbanxi

\begin{tabular}{|l|l|}
\hline Title & Genre \\
\hline Red Lantern & Opera \\
\hline Shajiabang (or Sachiapang) & Opera and symphony \\
\hline Taking Tiger Mountain by Strategy & Opera \\
\hline Raid on White Tiger Regiment & Opera \\
\hline Song of Dragon River & Opera \\
\hline The White-Haired Girl & Ballet \\
\hline On the Docks & Opera \\
\hline Red Detachment of Women & Ballet \\
\hline
\end{tabular}

After 1969 other model operas were produced. By 1976 the number of the model works had increased to eighteen, only ten of which were operas.

\section{Characteristics of the yangbanxi}

The reform of the Peking Opera towards more "modern" and "revolutionary" forms did not begin with the Cultural Revolution, as was mentioned above. Its beginnings, at least, may be traced to the end of the Qing period, when reformers exploited the Peking Opera as a means of defending the Republican Revolution. Later, playwrights such as Tian Han and Ouyang Yuqian, two founders of the modern spoken drama, decided to use the opera as a means of mobilization in time of war. Both believed that drama and opera were valuable means of transmitting contemporary themes and stories.

Certain characteristics exist which may be summarized and which help to define and understand the model works. The most important are:

- Libretto: many are a set of parts selected from literary works. ${ }^{31}$ That is, a reduction of a much longer text. However, it is expected that the public may relate the chosen part to the whole.

29. Qing, On the Revolution of Peking Opera, 51-52.

30. The piece mentioned as Taking Tiger Mountain by Strategy is also known as Taking the Bandits' Stronghold.

31. For example, the yangbanxi Taking Tiger Mountain by Strategy is concerned with chapters 10-21 of Qu Bo's book. 
- Characters: many characters (also "negative"), less useful to the political purposes of the regime, are eliminated or relegated to the background. The most useful ("positive") are highlighted (given more to sing, for example) and are always friends of the masses. There is no longer space to some characters from the traditional repertoire, such as the delicate Dan..$^{32}$ The communist heroines (some already of a certain age, others quite young) are proactive women, ready to join the armed struggle, a kind of courageous and fighting Qingyi, ${ }^{33}$ masculinized, who sings in the style of Xiaosheng. ${ }^{34}$

- Music: ${ }^{35}$ there is a conjugation of Western and Eastern musical elements. Barbara Mittler uses the expression "pentatonic romanticism." ${ }^{36}$ For example, the combination of traditional musical instruments from Chinese opera with an orchestra. Some Western ideas and musical principles may be identified in the yangbanxi, such as the use of the interval of the augmented fourth (the diabolus in musica) or musical passages copied from Mozart's Die Zauberflöte. Or, further, the particular example of the horns, in the musical description of the forest in the opera Taking Tiger Mountain by Strategy, very much in the style of German romanticism and Weber. Musically and semantically there are aspects that denote continuity with the Chinese operatic legacy, conveniently utilized in the service of the regime. This is the case with the Chinese percussion orchestra which not only accompanies each movement on the stage, from the long battle scenes to the movement of a glance, but which also reflects the thoughts and emotions of the singers. Another example is the continuity of the use of typologies of the Peking Opera, which may appear with different metres (for example, erhuang and xipi). The theory of "Three Prominences" is also translated into music by means of the so-called "Four Prominences," 37 which outlines the following guidelines: (1) among choralists and instrumentalists, choralists ought to dominate, (2) among Chinese instruments, the three main instruments in the operatic ensemble - jinghu, erhu, and pipa - ought to be emphasized, (3) among these three instruments, the fiddle jinghu should stand out, and (4) among Western instruments, stringed instruments ought to be foregrounded.

32. Dan is a typology of female characters subdivided into further categories. For example, Guimen Dan or Qingyi is the main role, generally a virtuous young woman; Daoma Dan is a young warrior woman; Wu Dan is a role in the female martial arts; Lao Dan is the role of an older woman, and so forth.

33. Main female character, a delicate young woman.

34. Male character, young.

35. See Dolores Hsu, "Musical Elements of Chinese Opera," The Musical Quarterly 50/4 (October 1964), 439-451; Alan Kagan, "Music and the Hundred Flowers Movement," The Musical Quarterly 49/4 (October 1963), 417-430.

36. Mittler, A Continuous Revolution, 45.

37. Ibid., 84 . 
- Wardrobe and scenery: there are substantial differences regarding the wardrobe, with the elimination of traditional costumes with characteristic colours and patterns. However, similar guiding principles were retained, such as the case of the symbology of colours, or the fact of there being a simpler and/or poorer costume for a role with these characteristics. There is a great simplification of the wardrobe, and systematic recourse to the use of military uniforms. The use of scenery and light effects is introduced, coming closer to the model of Western opera, in that the traditional forms of Chinese opera do not use scenery and use very few stage props. ${ }^{38}$

- Acrobatics: in the acrobatic parts, the yangbanxi give preference to more elaborate, impressive and daring moves.

- Gesture: gesture is worked on and developed to perfection. Posture, dance movements, facial expression, all reveal a deep loyalty to and veneration of Mao Zedong. Through gesture is demonstrated love for the working classes (the proletariat) and hate, both for the upper classes of the old social hierarchy and for foreign enemies, particularly the Japanese. Expressions are developed in order to show nobler aspirations, tenacity and bravery and also wisdom.

\section{Aspects of the production and reception of the new operatic heroines seen through the Kwok On Collection}

In the model works was created a heroic image of woman. The communist heroine, coming from the people, fought on the same level as the male hero, frequently having an even more important role. She would fight, until death if necessary, for the glory of the Party, never for her own personal glory. There is here an intersection between questions of gender and nation. The woman-nation is presented, firstly, as a victim of social oppression and, later, as a beneficiary of the socialist revolution. The new image of "modernity" associated with woman projected in her body and her will the socialist revolution. This automatically implied a rejection of all that was tradition and the acceptance of the coming of a modern era. The socialist system led woman out of her role as a "ghost of the old society" towards that of a "leader of a new state". Notwithstanding, this emancipation of woman is concomitant with a process of grouping by gender. Feminine sexuality, or the sensuality of the female body, is replaced by genderless or asexual symbols, which signify the socio-political collective. As in the image of Jiang Qing herself,

38. Usually a table and two chairs are used for a great number of scenes. 
who, from a certain time on, appeared in public dressed in a military uniform, masculinized.

The Kwok On Collection includes nine phonograms (vinyl discs) with excerpts of different yangbanxi: Red Lantern (opera, 5 discs; piano-accompanied version, 1 disc), Taking Tiger Mountain by Strategy (opera, 1 disc) and Shachiapang (symphonic version of the opera, 2 discs). Of the six phonograms of the Red Lantern, three belong to a single edition, ${ }^{39}$ two to another, ${ }^{40}$ different (all with excerpts from the opera) and the latter is the previously-mentioned piano-accompanied version. ${ }^{41}$ All the covers of these vinyl discs have a translation into English (and were therefore intended for the foreign Western market) with the exception of the collection which includes the two discs, with texts in Mandarin only. Taking Tiger Mountain by Strategy ${ }^{42}$ and Shachiapang ${ }^{43}$ also have a translation into English on the cover. The label that published all these vinyl records is Chinese Records. Through iconographical and iconological analysis of the record covers, it is possible to understand how the image of woman is instrumentalized with the aim of political propaganda. ${ }^{44}$

The Red Lantern was based on a film from 1963 entitled There will be followers, in turn based on a literary work, There will be Followers of the Revolution, by Qian Daoyuan, published in 1958. It was first given there, as the seventh art, and only afterwards as a staged opera. This work was created on the basis of a true story of a communist family (Tiemei - daughter, Li Yuhe - father and Li - grandmother) which supplied secret information about the Japanese invaders during the Second Sino-Japanese War. The protagonist works at the train station of Huicui in Hulin, a profession associated with the proletarian classes, from which comes the symbolism of the red lantern (a means of signalling, on the one hand, with the symbolic colour of the regime, on the other). The Red Lantern deals with the theme of the sacrifice of the working classes, of their contribution to the success of the War, of their links to the revolutionary cause, of their tenacity in the subworld of espionage and of possible martyrdom in executions, through three generations of a single family. This opera, with other, similar operas, had done with the cultural and aesthetic riches of the traditional Peking opera in the interests of

39. Catalogue no.: KO $0738(1,2,3)$.

40. Catalogue no. (unique): KO 0302.

41. Catalogue no.: KO 0744.

42. Catalogue no.: KO 0740.

43. Catalogue no.: KO 0744.

44. In the introduction to the book by Shuqin Cui, Woman Through the Lens, which touches upon questions of gender and nation in Chinese cinema, it is mentioned in this context: "The process of narrating the nation engages various discursive and textual productions ... The concept of nation is always changing and in process because sociocultural transformation never ceases. In the early twentieth century, for instance, the May Fourth, intellectuals called for a modern nation that would break away from tradition and engage with Western ideas. Enlightenment and cultural iconoclasm became discourses of national salvation." Shuqin Cui, Women Through the Lens - Gender and Nation in a Century of Chinese Cinema (Honolulu: University of Hawai'i Press, 2003), 7. 
transmitting more contemporary experiences, in conformity with the ideas of the time. It is therefore not surprising that the Red Lantern enjoyed success during the National Festival of Peking Opera in June 1964.

Analysis of the covers of the discs shows that the collection of three discs always used the same cover, which functions as a unifying element. The three principal characters are seen: Li Yuhe, Tiumei and Li. They are arranged in a small triangle, Li Yue, holding the lantern, being at the top. At the two angles further back (and at the base of the triangle) are the women, Tiumei and Li. The older woman raises her eyes to the infinite but touches Li Yuhe with her hand, symbolizing the matriarchal roots of the nation, which unconditionally supports the family. ${ }^{45}$ The younger woman, similarly gazing into the infinite, is dressed in red, a symbolic colour in Mao's China, establishing a deep connection with the colour, equally symbolic, of the lantern. She closes her fist, as does her father, in a symbol of resistance, courage and perseverance. A characteristic very particular to these three people is the gaze: it is not focused on anybody or anything; it looks towards the infinite, but transmits firmness, solidity and resistance. The traditional opera costumes are replaced by more up-to-date and informal clothing in order to obtain distancing from the earlier repertoire and earlier traditions. The beauty of the old wardrobe of the Dan is here totally neutralized and the feminine aligned (Figure 2).

The text chosen for the cover of the disc is made up of propaganda slogans and quotations from Mao Zedong, exalting the revolution. There is also a demarcation from the earlier repertoire in the indication that it is an opera with a "contemporary theme." The choice of the English language (the text of the disc is bilingual) shows that the Western market for recordings was being borne in mind. ${ }^{46}$

The other collection of two discs, with excerpts from the Red Lantern, does not have the text in English (Figures 3-4). The covers are once again photographs of the protagonists and show key moments of the opera. The three members of the family are portrayed in a completely different context. In the centre this time is the daughter, the new heroine, who takes on the revolutionary leadership. The father flees and is supported by her. He is chained, which relates to the end of the opera, when he is captured, tortured and killed by the Japanese. This new ar-

45. The family, sensu latu, also means the proletariat.

46. The cover says: "An outstanding example of theatrical art on revolutionary, contemporary themes". There is also the intention of reinforcing the quality of the recording and the musical product contained on the disc. It says that the opera is "Performed by the no. 1 Company of the China Peking Opera Theatre". On the reverse of the disc (also bilingual), at the top, is a quotation from Mao Zedong: "Thousands upon thousands of martyrs have heroically laid down their lives for the people; let us hold their banner high and march ahead along the path crimson with their blood." Underneath, on the right, is an excerpt from 'Hongqi' editorial (n8, 1967): "Under the guidance of Chairman Mao's proletarian line on literature and art, Comrade Jiang Qing and the revolutionary literary and art workers put up a strenuous struggle to overcome many obstacles, and have already produced a number of revolutionary Peking operas and ballets and a revolutionary symphony, all reflecting the brilliance of Mao Mao Zedong's thought. These works are full of militancy and proletarian revolutionary heroism. They are models in serving the workers, peasants and soldiers and the dictatorship of the proletariat. They are gems in the treasury of proletarian literature and art, precious works in the art history of mankind." 
Figure 2 Cover of vinyl disc, Red Lantern, Chinese Records, n.d. Kwok On Collection, Fundação Oriente. (C) Author's photo

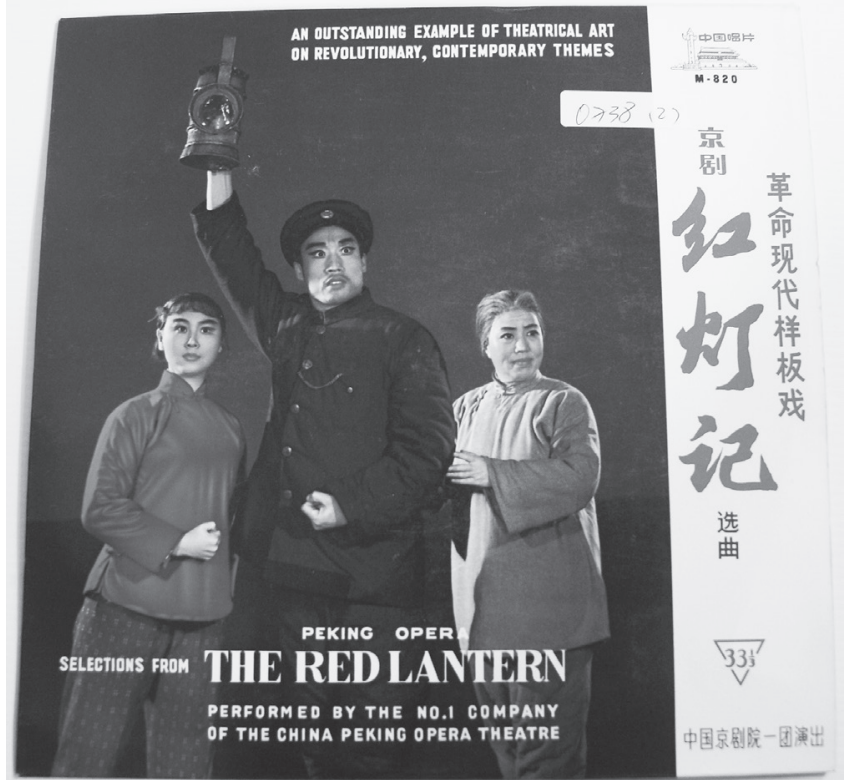

Figure 3 Cover of vinyl disc, Red Lantern, Chinese Records, n.d. Kwok On Collection, Fundação Oriente. (C) Author's photo

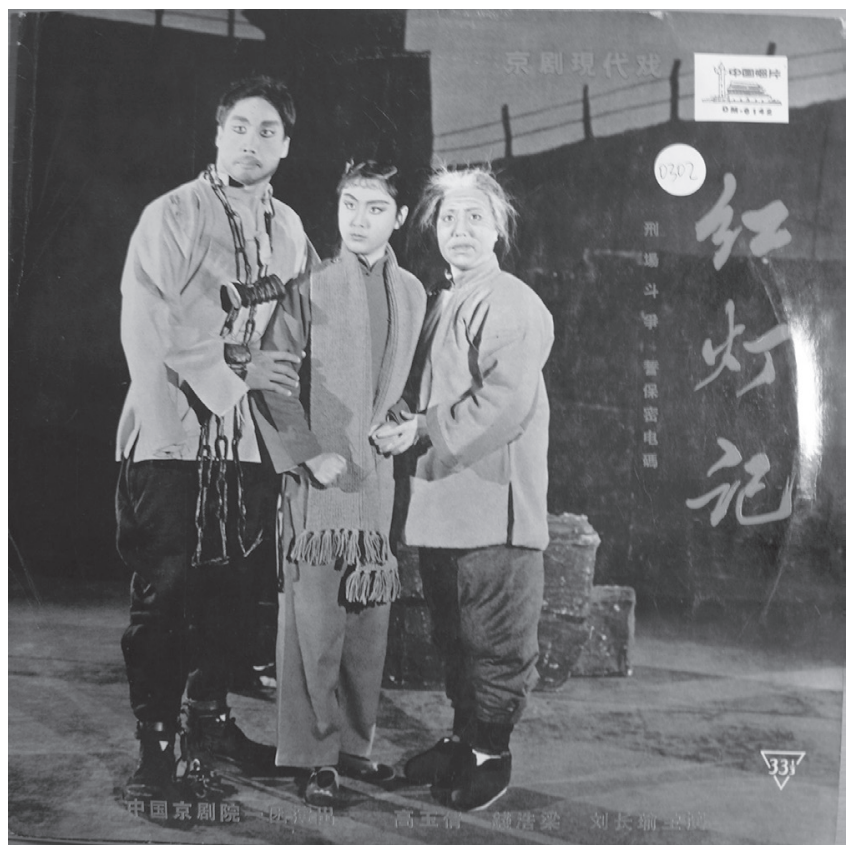


FiguRe 4 Cover of vinyl disc, Red Lantern, Chinese Records, n.d.

Kwok On Collection, Fundação Oriente. (C) Author's photo

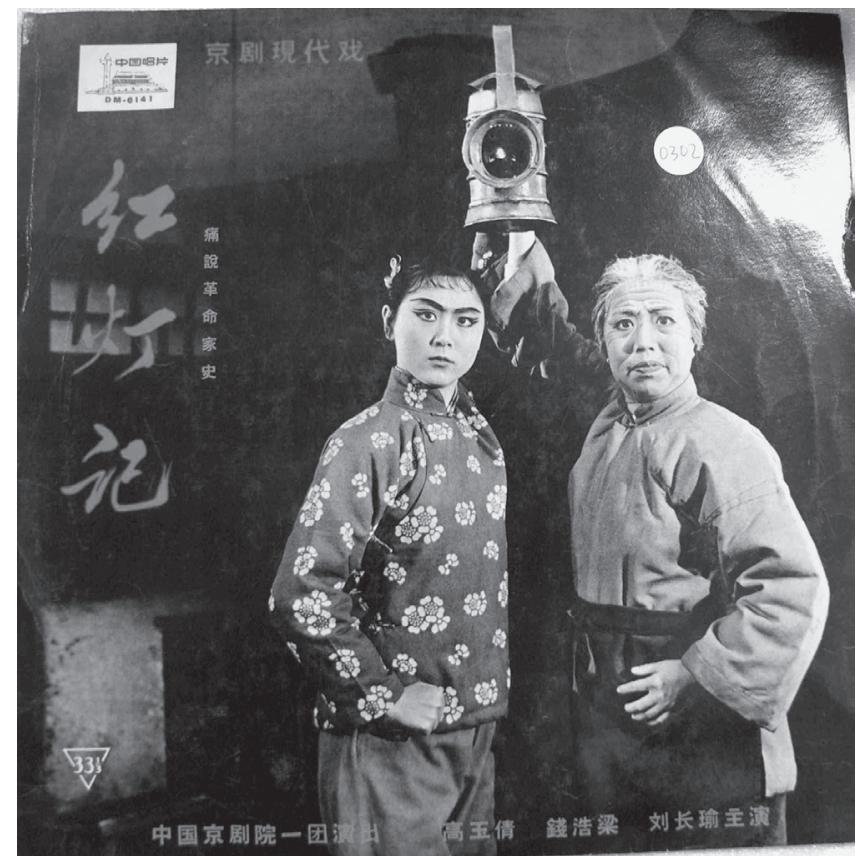

rangement of the characters shows us that it will be Tiumei, the daughter, leading the revolution. The new heroine is supported by the matriarch, the grandmother Li, who holds her hand.

The second disc of the collection shows only the two women, alone, having become leaders. As a sign of revolution and struggle, both raise up the red lantern, the symbolic element of the opera, belonging to the male hero, who has died in the communist cause. Here one clearly sees the new role of the woman, heroine, body and soul of the nation, motherland of all workers. Once again, the facial expression, determined gesture, taken to the limit of perfection, to represent the indomitable strength which it is wished to associate with Mao's regime. Her capacity for leadership, after the death of her father, associated with her youth, transmit to the spectator the security necessary for the flourishing and strengthening of the regime, as though she were a "young mother" (or "young nation"). The image of a girl, young sexually, brings the confidence of growth, of maternity, of descendants through the future generations. ${ }^{47}$

47. See also Rosemary Roberts, "Gender and Psychology in the Women of The Red Lantern in its Evolution from Model Opera to Soap Opera," New Zealand Journal of Asian Studies 12/1 (June 2010), 93-109; and Rosemary Roberts, Maoist Model Theatre - The Semiotics of Gender and Sexuality in the Chinese Cultural Revolution (1966-1976) (Leiden, Boston: Brill, 2010). 
Liu Changyu (who took the role of the young Tiumei) became an icon representative of this opera. In addition to the record covers shown above, she may be found in photographs, posters and periodicals, and even in caricatures (Figures 5-7).

FIgure 5 Poster (detail), Liu Changyu, Red Lantern, Kwok On Collection, Fundação Oriente. (C) Author's photo

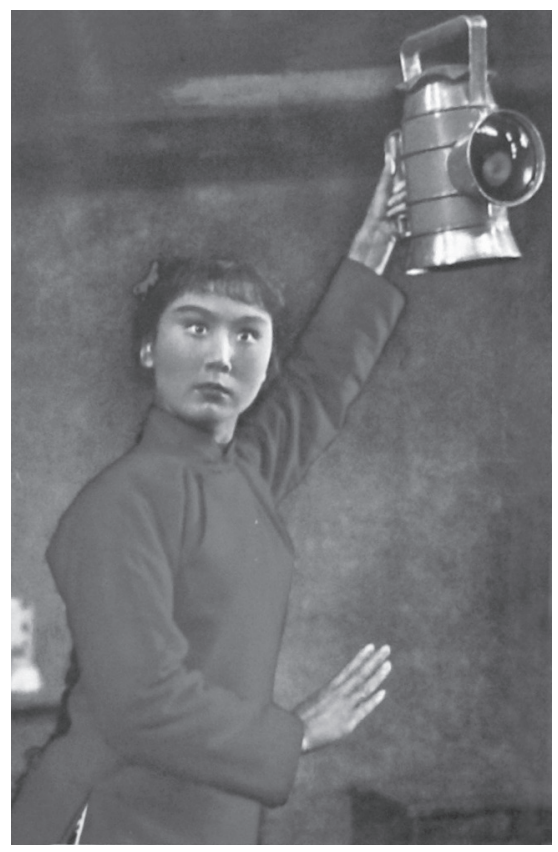

The disc with the piano-accompanied version has a completely different cover (Figure 8). The listener of this disc, even without understanding the Chinese alphabet, would have an immediate idea of the theme, of the title, of the "Leitmotif-object" of the opera. The emphasis is placed on the red background, on the red letters and rays of sunlight (colours symbolic of the nation). We see a concert piano, open. At the top, a red lantern is the centre of a gleaming sun, the analogy with Mao Zedong, the "red sun" who irradiates and illuminates the nation being obvious. The association between the sun/red lantern and the piano shows the "blessing" of Mao Zedong on the musical opening towards the West and his unquestionable support of the musically (and politically) decision for this new version.

The piano-accompanied version of this opera was made by the pianist of the regime and of the "Gang of Four," Yin Chengzong (1941-). ${ }^{48}$ Musical excerpts

48. His official online biography reads: "Pianist Yin Chengzong is widely recognized as one of the most renowned Chinese pianists in the world. Since his debut in 1983, Yin has appeared at Carnegie Hall for seven seasons. Concertizing in all five continents, Yin frequently performs in China, the United States and Russia. 
FIgURE 6 Magazine with propaganda (detail), Liu Changyu, Red Lantern, Kwok On Collection, Fundação Oriente. (C) Author's photo

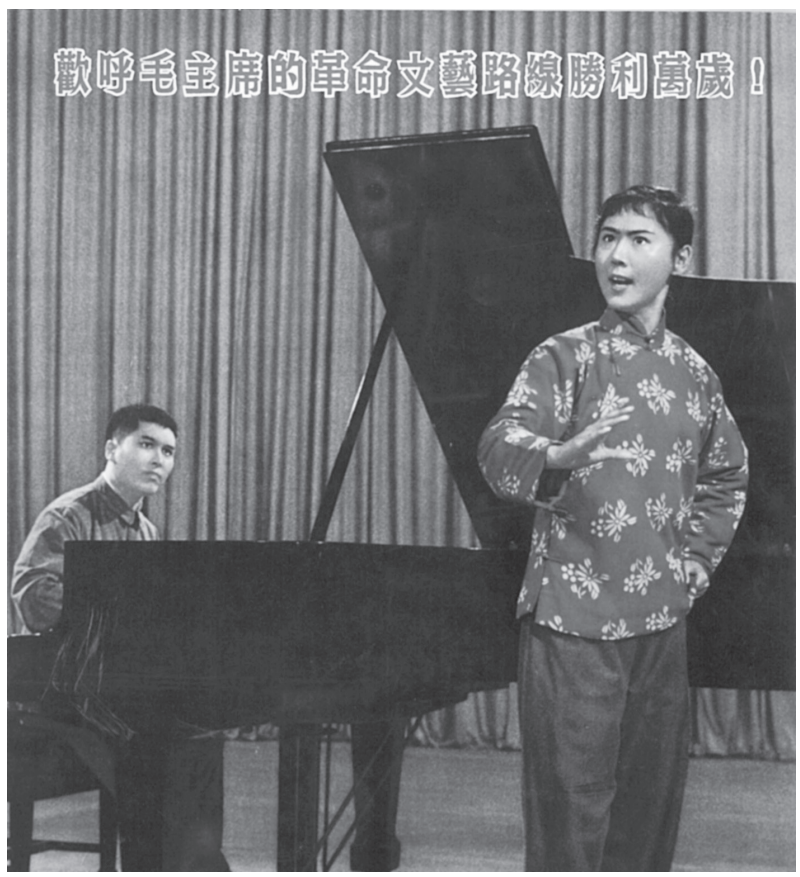

from the work would be published in propaganda magazines, whether in numerical musical notation (known as "Jianpu") or in Western staff notation. ${ }^{49}$ In a propaganda magazine in the Kwok On Collection, there are "Jianpu" scores with excerpts from The Red Lantern. The first is one of the best-known, "The whole body is filled with courage and strength" (Figure 9). This scene corresponds to a dramatic moment in the action, when the male protagonist, Li Yuhe, is invited by the Japanese under false pretences. Li Yuhe knows that the invitation masks his

Yin has performed under the baton of Eugene Ormandy with the Philadelphia Orchestra, Claudio Abbado with the Vienna Philharmonic Orchestra, Kirill Kondrashin with the Moscow Philharmonic Orchestra and Sir Malcolm Sargent with the St Petersburg Philharmonic Orchestra. Highlights of Yin's recent engagements include Beijing's National Centre for the Performing Arts, as well as solo recitals in Toronto, Boston, San Francisco and Washington, D.C. Performing his first solo recital at nine, Yin Chengzong won the Gold medal at the International Vienna Youth Piano Competition at 17. He was a Silver prize winner at the International Tchaikovsky Competition at age 20. He created/premiered The Legend of the Red Lantern, piano with the Peking Opera in 1968. Yin became well-known for composing and performing the Yellow River Piano Concerto, as well as for writing/publishing 'Ancient Chinese Music for Piano' in the 70s. Yin was listed in the New Grove Music Dictionary in 1980 edition. Having released more than 30 albums, Yin Chengzong has appeared in five documentaries and was featured on CCTV, CBS and Phoenix TV." Yin Chengzong, accessed December 13, 2019, http://www.yinchengzong.com/Yin_Chengzong/Yin_Chengzong/Short-Bio.html

49. On the page preceding the score, readers of the magazine are informed that they can find the version in Western staff notation in the Illustrated People's Magazine, no. 9, also published in 1968. 
FIGURE 7 Magazine with propaganda (detail), drawing (or caricature?) of Liu Changyu, Red Lantern, Kwok On Collection, Fundação Oriente. (C) Author's photo

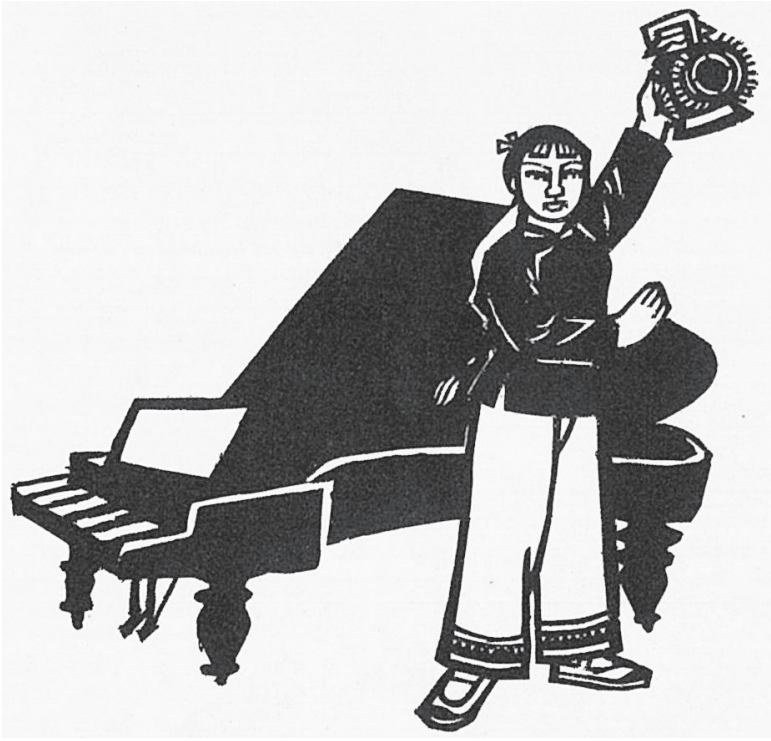

FIGURE 8 Cover of vinyl disc, Red Lantern, piano-accompanied version, Chinese Records, n.d Kwok On Collection, Fundação Oriente. (C) Author's photo

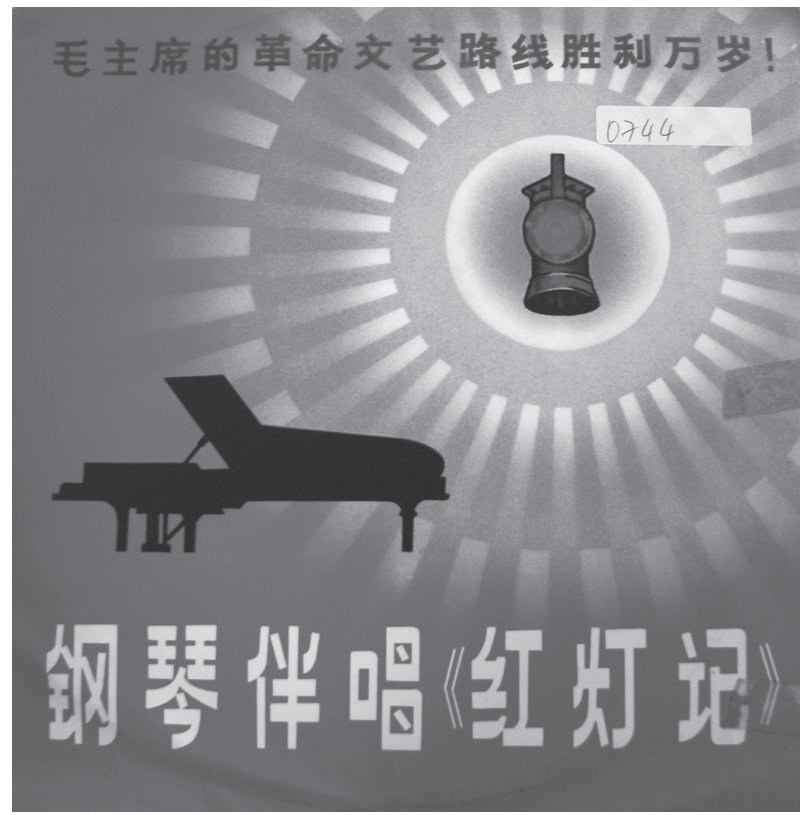


FIGURE 9 Jianpu excerpt from the opera Red Lantern, Kwok On Collection, Fundação Oriente. (C) Author's photo

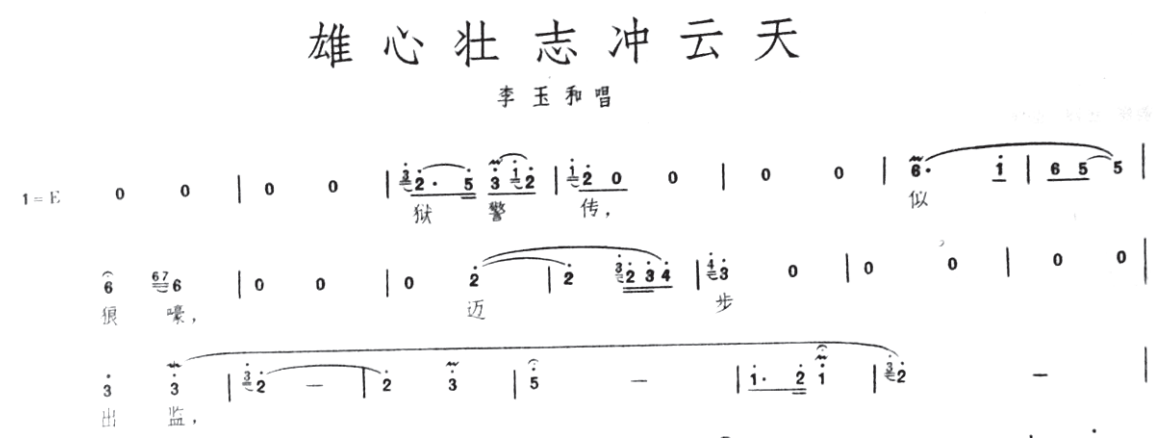

future prison, torture and death. Before leaving, he drinks a glass of wine, singing "Before leaving I drink a glass of my mother's wine and courage fills my entire body." ${ }^{50}$ The score indicates, on the right side and underneath the title, that this is the monologue "Thank you, Mother."

Analysis of this example of "Jianpu" shows that the tonality is E major, through the indication $1=\mathrm{E}$ on the left side.$^{51}$ This means that the tonic (E) corresponds to the number 1 . From this the rest of the notes may be deduced $(1=\mathrm{E}, 2=\mathrm{F}, 3=\mathrm{G}$, $4=\mathrm{A}, 5=\mathrm{B}, 6=\mathrm{C}, 7=\mathrm{D}) .0$ (zero) indicates a rest. Dots placed above or below the numbers mean that they should be played, respectively, an octave (or multiples thereof) higher or lower, depending on the number of dots (one dot, one octave; two dots, two, etc.). Duration (rhythm) is indicated by dashes. A number (note) with no dash equals a crotchet (1 beat). A number followed by three dashes equals a semibreve (four beats), with one dash equals a minim (two beats), with an underline a quaver (half-beat), with two underlines a semiquaver (a quarter-beat). Bar lines, ligatures, ornaments, fermatas and other musical symbols common in Western notation are also used.

In other items in the Kwok On Collection, the female is given significant emphasis in its relationship with the red sun (Mao Zedong). On the cover of a vinyl disc of the ballet The White-Haired Girl, we see the veneration of a heroine by the leader and by the nation (Figure 10). In this yangbanxi the story is based both on legends and on real facts from the border region of Shanxi, Chahar and Habei, telling of the misery and suffering of the local peasants, especially the women. Again, it is a woman who determines the revolt of the lower classes against the "feudalism" of the landowners. To the plot is added political propaganda and facts which extrapolate the reality, especially the end, in which the heroine joins the communist forces. 
FIGURE 10 Cover of vinyl disc, The White-Haired Girl, China Record, n.d. Kwok On Collection, Fundação Oriente. (C) Author's photo

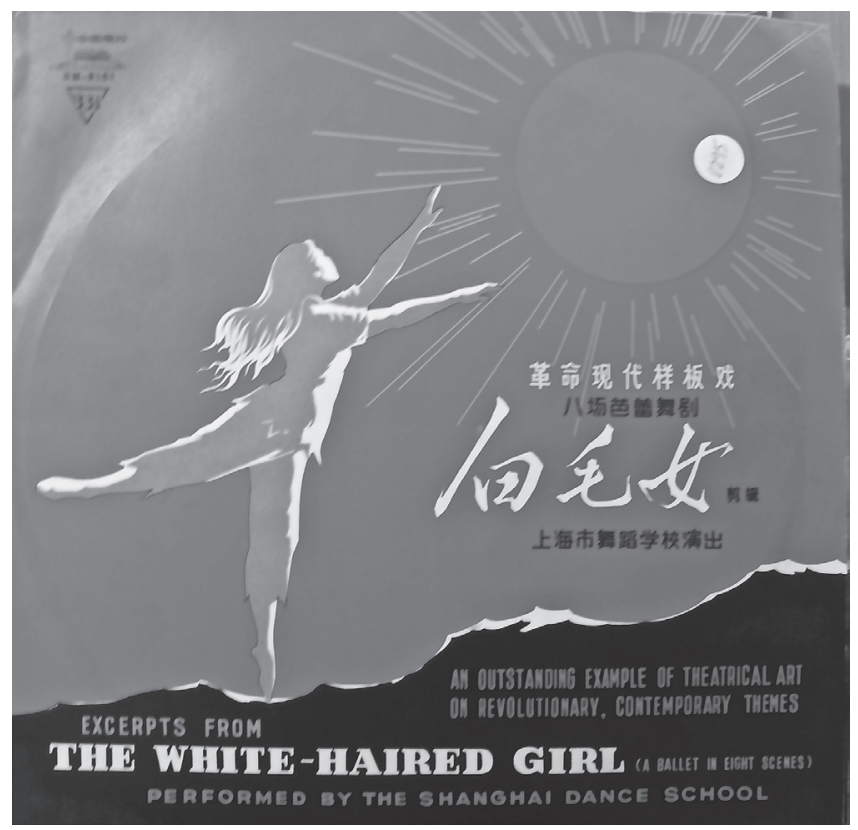

This ballet is the chief element in one of the regime's most curious kinds of political propaganda. Innocent and playful in character, two puzzles portray key scenes of the work and are powerful weapons of propaganda (Figures 11-12). The first shows the revolt of the heroine (still with black hair) against the feudal lord, who had kept her as a slave. The second, the final scene, in which, now free, and transformed, with white hair, the girl takes her vengeance by attacking him. These puzzles are one of the most interesting and unexpected aspects of the dissemination of the yangbanxi and of the regime of Mao Zedong to be found in the Kwok On Collection.

Another interesting propaganda medium is the paper cut-out. Moreover, the actual plot of this yangbanxi makes mention of this Chinese tradition. The story takes place on the evening of a feast in celebration of spring. When the heroine, the peasant Xi'er, is awaiting the return of her father in order to go together to the celebrations, her friends appear with paper cut-outs, with which they used to decorate the windows. The cut-outs represented here use red as the base colour and display the main episodes of the story (Figures 13-14). A detail that indicates extreme care and a certain refinement is the fact of Xi'er having cut-outs in which she appears with black hair (the beginning of the story) and with white hair. In the first example shown here, Xi'er rebels against her feudal lord; in the second, Xi'er, now with white hair, dances at the side of a soldier of the Communist Party. 
Figure 11 Puzzle, The White-Haired Girl,

Kwok On Collection, Fundação Oriente. (C) Author's photo

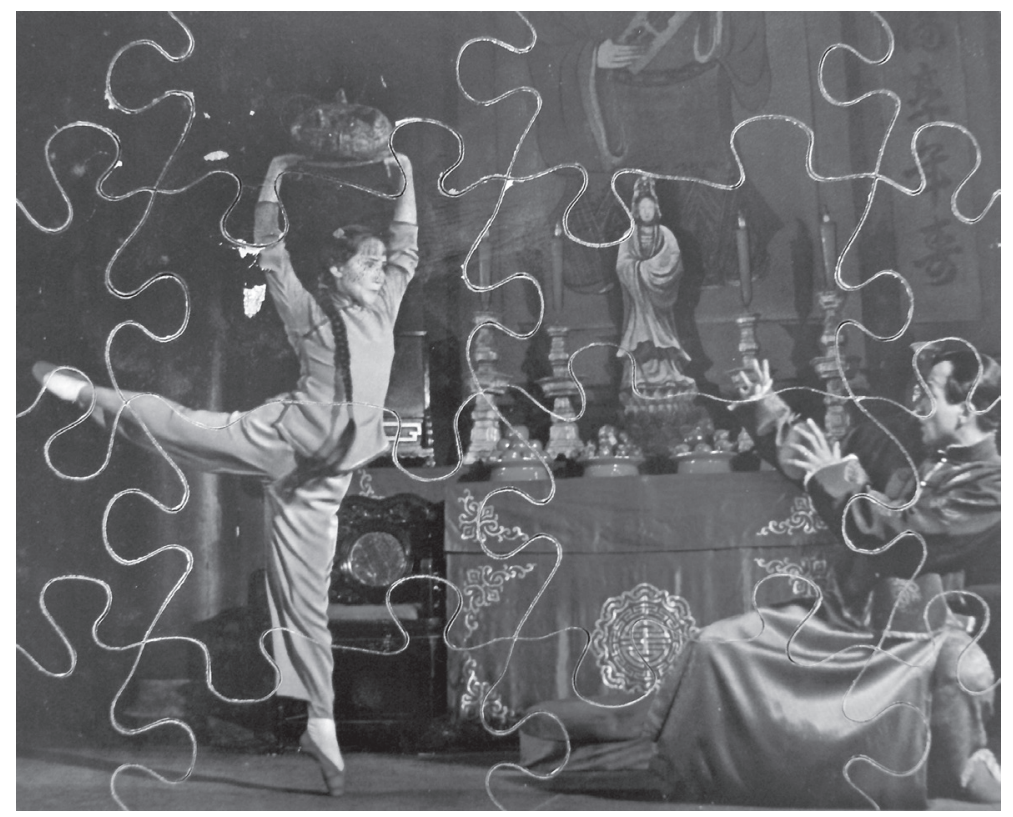

Figure 12 Puzzle, The White-Haired Girl,

Kwok On Collection, Fundação Oriente. (C) Author's photo

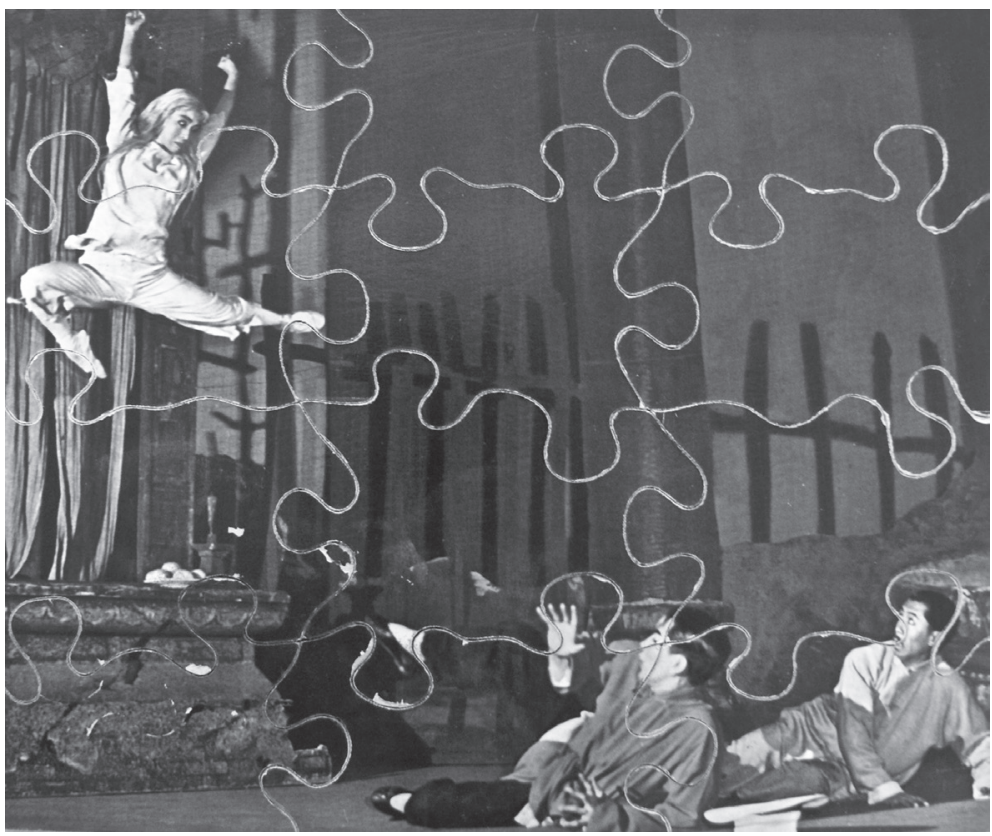


FIGURE 13 Cut-out, The White-Haired Girl,

Kwok On Collection, Fundação Oriente. (C) Author's photo

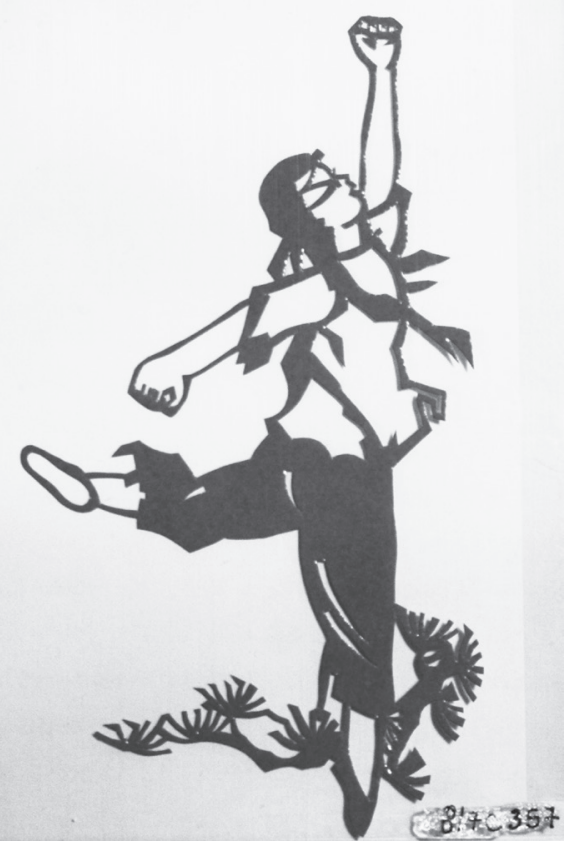

Figure 14 Cut-out The White-Haired Girl,

Kwok On Collection, Fundação Oriente. (C) Author's photo

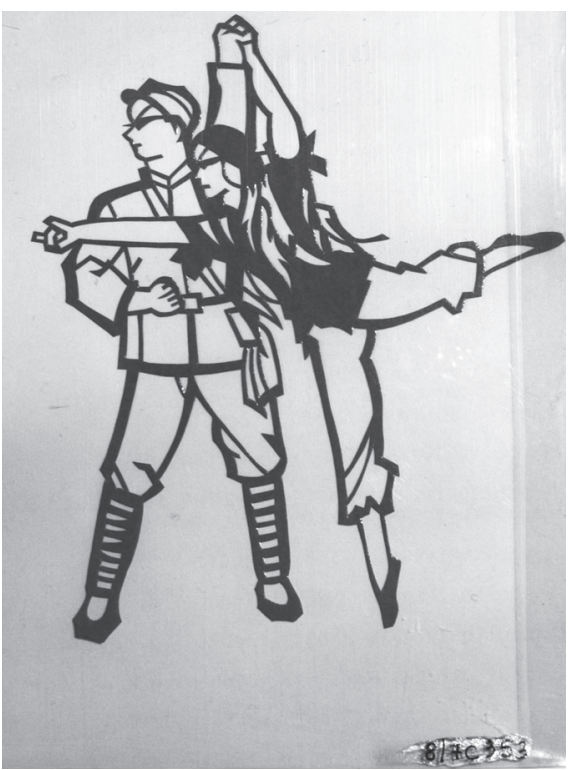


FIGURE 15 Cover of vinyl disc, Taking Tiger Mountain by Strategy, Chinese Records, Kwok On Collection, Fundação Oriente. (C) Author's photo

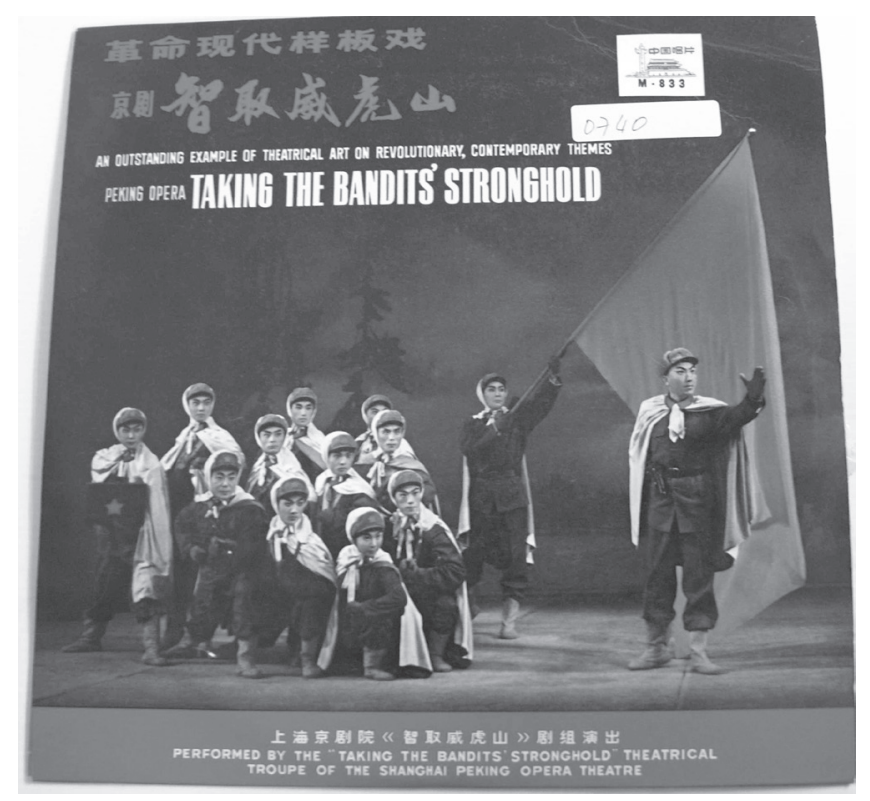

The opera Taking Tiger Mountain by Strategy was based on a novel by $\mathrm{Qu}$ Bo, Linhai Xueyuan (Tracks in the Snowy Forest), from 1957, also being adapted for film in 1960. The opera makes use of only a part of the book. It takes place in Manchuria, in 1946, and deals with the struggle between the soldiers of the People's Liberation Army and a group of bandits who support Guomindang and who kidnap and kill some villagers. The hero is Yang Zirong, the platoon leader. Yang is sent by Shao Jianbo, the leader of the regiment, to infiltrate himself in the bandits' fortress in order to discover when and how to attack their leader, Zuo Shandiao, and his group.

On the cover of this vinyl disc may be seen in the background a forest scene, dark and snowy, in the style of Western romantic opera (Figure 15). In the foreground is the hero, Yang Zirong. Behind him, a soldier holds the red flag that, strategically, frames the hero. The white capes placed over the uniforms are part of the soldiers' camouflage, need because of the snow on the mountain of the Tiger. We see applied in this image the theoretical directives of Jiang Qing, in the emphasis on "positive" characters. In the group of soldiers, which is carefully aligned behind Zirong, in attack position, are some women. If it were not for the feminine traces of the faces, it would be almost impossible to distinguish them from the male soldiers. Feminine nature has been abolished, and these are figures of an androgynous nature. There are no traces of femininity, or sexuality. On the 
FIGURE 16 Cover of vinyl disc, Shachiapang (symphonic version), Chinese Records, Kwok On Collection, Fundação Oriente. (C) Author's photo

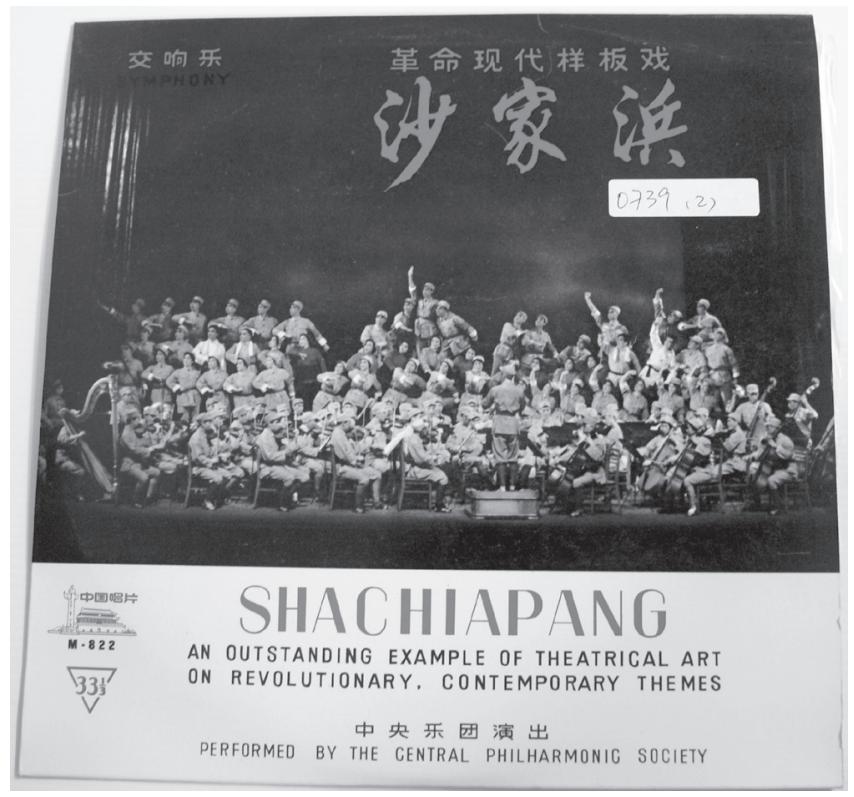

other back of the cover, as is the case with The Red Lantern, is quoted the editorial no. 8 of Hongqi, 1967, which contains quotations from Mao Zedong.

Shachiapang is given, on this recording, in the symphonic version (orchestra and choir). The stage with the orchestra is seen (Central Philharmonic Society), as well as the conductor and the choir. It is important to note that the orchestra and conductor wear uniforms of military style, grey in colour, with a red band on the arm. The choir wears, for the most part, the same un iform. Some members (two men and ten women) wear clothes in the style of the peasant classes (Figure 16).

\section{The reception of the yangbanxi through the vision of the feminine}

The generations marked by the yangbanxi were catalysers of feelings and emotions which extended, in a vibrant fashion, into the 21st century. Analysis of questions of reception will, in this article, be made essentially through a feminine perspective. Such an approach implies understanding the way in which this "woman-nation," the new heroine of the operas, appears and directs herself towards the spectators and citizens of China and the West. The dissemination of ideas through plots, choreography, scenery and music was carried out in an overpowering way, highly controlled and with recourse to various means of communication - audio (such as 
radio), visual (such as posters, postcards, stamps, etc.) and audio-visual (cinema and television). Unlike the West, where opera was always one of the preferred genres of the elites, Mao's China used it as a form of art intended for the masses.

It is important, to understand better the iconographic objects that had to do with the Cultural Revolution, to analyse some sources from outside the Kwok On Collection. The first analysis is of the report by Anchee Min, a Chinese-American author, ${ }^{52}$ who wrote a biographical work entitled The Red Azalea. This is a set of memoirs of her life in the last years of Mao's government. ${ }^{53}$ As a child, she was asked to humiliate a teacher publicly; at seventeen, she was sent to a collective farm. Forbidden to speak, dress, read, write or love as she wished and freely, she found strength and guidance in a secret love affair with another woman. Miraculously selected for the film The Red Azalea, Min's life changed radically. However, President Mao died at that moment, taking with him an entire world, the only world that Anchee Min knew. Her memoirs, characterized by an exceptional sincerity, provide us with a revealing and disturbing portrait of China during the Cultural Revolution:

I listened to operas when I ate, walked and slept. I grew up with the operas. They became my cells. I decorated the porch with posters of my favorite opera heroines. I sang the operas wherever I went. My mother heard me singing in my dreams; she said that I was preserved by the operas. It was true. I could not go on a day without listening to the operas. I pasted my ear close to the battle until all the beasts are killed. It was sung by Iron Plum a teenage character in an opera called The Red Lantern. I would not stop singing the aria until my vocals cords hurt. I went on pushing my voice at its highest pitch. I was able to recite all the librettos. ${ }^{54}$

52. Anchee Min was born in Shanghai in 1957. At the age of seventeen, she was sent to a collective work camp, where talent scouts recruited her to work as an actress. She sought asylum in the USA in 1984, with the help of the actress Joan Chen. She has concentrated on writing, painting, photography and music. She lives in Los Angeles and Shanghai with her husband and daughter.

53. In the same way, the book by Zhu Xiao-Mei, O rio e o seu segredo (Lisboa: Guerra e Paz Editores, 2007) is compatible with Anchee Min perspective of Cultural Revolution. Zhu Xiao-Mei was born to middle-class parents in post-war China, and her musical proficiency became clear at an early age. Taught to play the piano by her mother, she developed quickly into a prodigy, immersing herself in the work of classical masters like Bach and Brahms. She was just ten years old when she began a rigorous course of study at the Beijing Conservatory, laying the groundwork for what was sure to be an extraordinary career. But in 1966, when Xiao-Mei was seventeen, the Cultural Revolution began, and life as she knew it changed forever. One by one, her family members were scattered, sentenced to prison or labour camps. By 1969, the art schools had closed, and Xiao-Mei was on her way to a work camp in Mongolia, where she would spend the next five years. Life in the camp was nearly unbearable. Yet through it all Xiao-Mei clung to her passion for music and her sense of humour. It was the piano that helped her to heal and she became famous for her recording of Bach's Goldberg Variations.

54. Anchee Min, Red Azalea (New York: Anchor Books, 1994), 15-16. 
Anchee Min also makes clear the new role of women, as heroines of the regime and of opera. She also points out the modernity of the "film-operas," and the idea of Jiang Qing:

Comrade Jiang Qing was trying to develop something new in China, trying to combine film and opera although no one knew how to make films work. The result was films with a strong flavour of opera - the makeup, the lighting, the stylized voice and pose. And now it was the proletariat, and in particular women, who were the heroes. People all over China had to see the films or be labelled reactionaries. ${ }^{55}$

The way in which opera moulded its heroines dictated the course of Anchee Min's personal life. The lack of sexuality in the operatic productions left young Chinese girls without access to the world of the imagination that many children in the West begin to have from early on through animated films, cartoons, books and so on. Consequently, there was an incapacity of constructing models and future lives. The expression of love and of the more intimate feelings could not be carried out freely, leading to emotional repression. In the case of Anchee Min, Yan, one of the directors of the collective farm to which she was sent, became her heroine in opera and in life, her way of channelling emotions and an emerging sexuality.

I learned ... to stay clear of men. I looked up to the model women society praised. The heroines in the revolutionary operas had neither husbands nor lovers. The heroine in my life, Yan, did not seem to have anything to do with men either. ${ }^{56}$

During a later phase of her life, already working for the regime as the protagonist of The Red Azalea, Anchee Min contested the emotional vacuum typical of the heroines of such productions. The lack of romance, love, lovers and deep feelings in the lives of these heroines seemed to her false and artificial:

He [the opera/film supervisor] said that he himself was not satisfied with the operas. He said that he craved revolutionary passion and many of the operas lacked it. I said that I agreed with him and said that I would be interested in the private lives of the characters. I said that it was strange to me that the opera protagonists had no private lives. He said, You mean romance? ... He said it was true that none of the model operas had romance. I said, I don't believe that the protagonists had no lovers in their lives whatsoever. I don't believe any human's mind could be so free of deep emotions. ${ }^{57}$ 
While in the service of the studios, as one of the candidates for the leading role, Anchee Min was subjected to severe competitiveness and an almost complete annihilation of her personality. The work of the character was carried out so that her own identity was practically destroyed. The supervisor of the production desired that she should incarnate, in a definitive fashion, a new being, the heroine of the opera. The production aimed to give the idea of female liberation, a woman, who fights for the party and the nation, sexually free, in a new China. Such an image was, obviously, nothing more than pure fiction.

I no longer cared whether other people would enjoy Comrade Jiang Ching's opera heroines. Red Azalea had become my life. ... From this moment on, I want you to forget your family name. You are Red Azalea now, said the Supervisor. Let me hear your name, please. I shivered and pronounced it loudly: I am Red Azalea. He nodded with satisfaction. ... Show me your determination, he murmured. I stared into his eyes. Yes, beautiful. You see, we are going to go through a forest of guns and a rain of bullets to pay respect to our mothers. Mothers who, for thousand of years, lived their lives in shame, died with shame, were buried and rotted in shame. We are going to tell them, Now it is a new world. A world where being born female merits celebration and salute ... A world where a woman who is forced to marry a pig can have an affair. ${ }^{58}$

The second analysis will be a reading of the documentary film of Yan Ting Yuen, ${ }^{59}$ in which various figures (singers, musicians, dancers, conductors, playwrights, etc.) active in the opera world during the period of the Cultural Revolution are interviewed, as well as spectators who still remember them. The testimony of one singer is remarkable, a singer who specialized in the traditional role of Dan, called Zhang Nan Yun. On account of her beauty and femininity (envied by Jiang Qing), and of her links to the old operatic models, playing the roles of heroines considered "feudal," she was forced to leave the stage. Her husband and her entire family were persecuted, imprisoned and sent to forced labour camps. Zhang Nan Yun never acted again. An opposite case, with similarly serious consequences, was that of the favourite ballerina of the regime, star of The Red Detachment of Women. Xue Qing Hua was nineteen years of age when the Cultural Revolution began. She says that she had no idea, at the time, of all the aspects of the Cultural Revolution and who Jiang Qing was. She only wanted to dance, and dance was the most important thing to her. It was therefore not difficult to take advantage of all

58. Ibid., 276, 280-281.

59. The film (The Netherlands, 2005, 90 minutes) was entered in the World Documentary Competition Sundance 2005. This film shows fragments of original performances of the yangbanxi, from the time of Mao, combining fragments of history with interviews and excerpts from contemporary performances, https://vimeo. com/114648184 (last accessed February 2 2016). 
the opportunities with which she was proved. And the enormous popularity she achieved is unsurprising. She was one of the stars of Jiang and of Mao's regime:

I got the best artists from all over China together. Young people who were enthusiastic about my ideas. As if I was working on a fairytale-like Hollywood musical ... But my work was better, my Yang Ban Xi really had something to say ... No expense was spared to make everything look as good as possible ... Overnight I became the best-known media figure. I was on the radio and my picture was in all the newspapers. ${ }^{60}$

With the fall of the regime, Xue Qing Hua also fell. Associated with the image of Jiang Qing, she was immediately removed from the theatres and confined to a life of hard labour. Only very recently was she called to help and collaborate with the stage revivals of the yangbanxi. In her words, the consequences were these:

There are ups and downs in political movements ... When the Gang of Four fell from power and people around me said I had a good relationship with Madame Mao, I became a suspect person and my person was investigated. I wasn't allowed to do anything any more, not even ballet dancing. So, I became a seamstress, I made shoes and clothes. I still remember my first raise in salary. It wasn't much. Only 7 yuan. But somebody said: "She was a favourite of the Gang of Four. She shouldn't get such a raise in salary." I felt so helpless because of those conflicts and those groups. And playing in The Red Women's Detachment had only brought disaster. It had brought me nothing but disaster. ${ }^{61}$

A masculine look at the ballet The Red Detachment of Women shows a new way of viewing the yangbanxi in their relationship to questions of gender. This example was chosen because it is the only case in which a woman/operatic heroine is treated with a certain eroticism. This variation in the profile may be explained by the fact that the ballet was based on Western models, more precisely the models of Hollywood. Certainly, the visit of Richard Nixon to China, in 1972, and the fact of this being the work presented for the American president during his stay there, dictated the Hollywood-style performance, modern and daring, in order to counter the established idea of the East as a closed and dictatorial communist regime. ${ }^{62}$ The characterless wardrobe, with long, masculine clothing, of simple appearance - so evident on the covers of the discs of the Red Lantern analysed above - is

60. Transcription of an excerpt from the documentary by Yan Ting Yuen.

61. Transcription of an excerpt from the documentary by Yan Ting Yuen.

62. It was also this visit that inspired the three-act opera Nixon in China. With a libretto by Alice Goodman and music by John Adams, the work was premièred at the Houston Grand Opera, on 22 October 1987, in a production by Peter Sellers with choreography by Mark Morris. 
replaced by an utterly different version. In the hairstyles and modern makeup of the soldier-dancers, in the sensual uniforms allowing the legs to be seen, is an attempt to reflect in the heroine-woman a (false) image of a modern, westernized China. The impact that such an opening had marked a generation of Chinese men. $\mathrm{Xu}$ Yi Hui, 39 years old, recalls and sings ${ }^{63}$ some of the yangbanxi melodies that stayed in his memory and the impact on his sexuality that the unexpected opening towards the feminine in The Red Detachment of Women brought him (Figure 17):

They're engraved in our memory. We watched them as a child. There was nothing to see except Yang Ban Xi. It made a deep impression on us. Of course, there was nothing else to see. I liked them all, especially The Red Detachment of Women ... because the women wore very little. And we were just beginning

FIGURE 17 Poster (detail), The Red Detachment of Women, Kwok On Collection, Fundação Oriente. (C) Author's photo

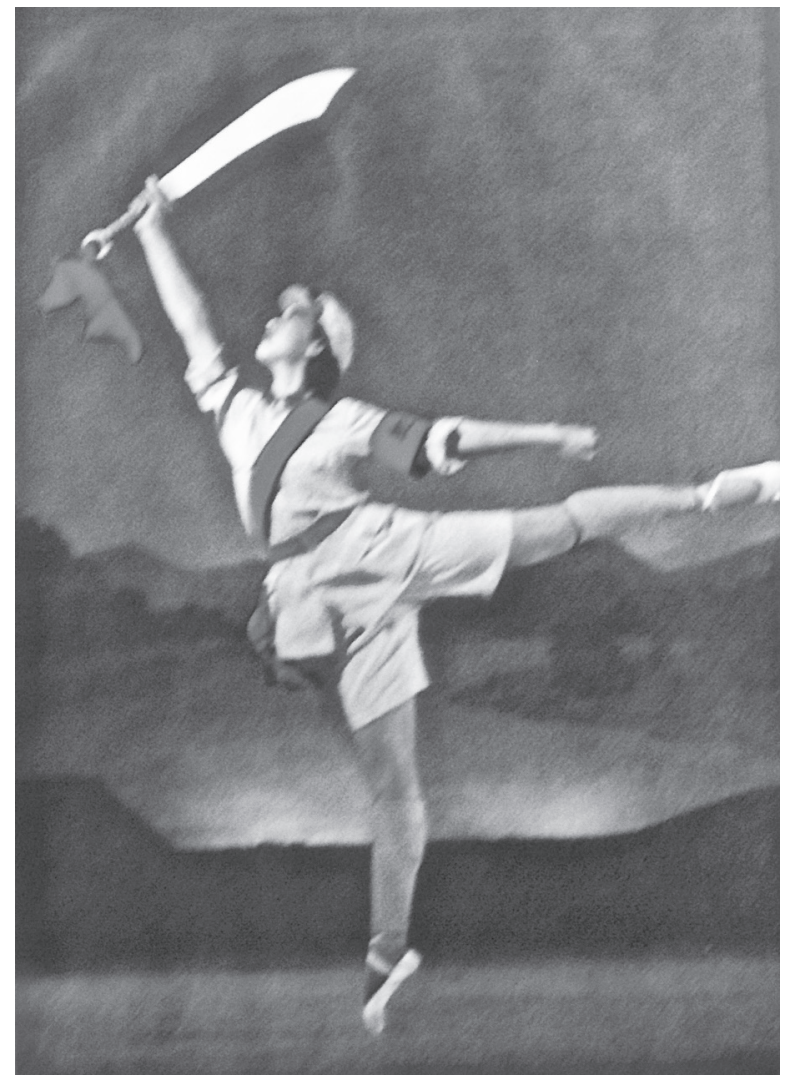

63. In the documentary by Yan Ting Yuen. 
to be attracted to the opposite sex. Our first sexual feelings were aroused by Yang Ban Xi ... At least we'd discovered something real in the Revolution. ${ }^{64}$

The vision he has of the opera is curious: a process of alienation. In a very lucid way, he points out that the way the yangbanxi portrayed the proletariat and the masses was very different on stage from real life, and that a far more painful reality was hidden behind the beauty of the stage:

It becomes theatre. A hallucination. Behind the theatre something was hidden: the painful reality of that period. And that is exactly what art should do. Art should hide reality so that you enter a fantasy world. That means that the pain inside is no longer real and will not be felt. ${ }^{65}$

This documentary also shows that the yangbanxi are once more gaining popularity amongst young people. Thus, there opens a window onto contemporary urban life. Young people organize flash mobs and dance with synchronized choreography. The traditional melodies of these model operas are remastered with new beats, in hip-hop style.

\section{Some aspects of the music of the yangbanxi seen through the sound analysis of the vinyl discs from the Kwok On Collection}

At this point, it is possible to understand that those works are full of references that demonstrate the process of fusion between the music of traditional Chinese opera and that of Western opera. The use of Leitmotif is evident, for example, in the Red Lantern, but also the melodic formulas of the old Chinese operas. Some attempts were made at using a Western orchestra; the Red Lantern already needed seventeen musicians, playing twenty-five instruments ${ }^{66}$ which contrasted with the use of the traditional orchestra of Chinese opera, which had eight or nine instruments and even fewer players.

The greatest musical resemblance between the Red Lantern and the West is found in the piano-accompanied version. The arias chosen sound very Western and the way of singing and of voice production are also similar. The pianist who made the recording and the arrangements was Yin Chengzong (b. 1941), the pianist of the regime. This window open onto the West, at a time when the aim was to exalt the great Chinese socialist revolution, may seem strange. In the documents

64. Transcription of an excerpt from the documentary by Yan Ting Yuen.

65. Transcription of an excerpt from the documentary by Yan Ting Yuen.

66. Richard Yang, "The Reform of Peking Opera under the Communists," The China Quarterly vol. 11 (September 1962), 124-139, 171. 
publicizing this performance (such as the cover of the above-mentioned vinyl disc), the image of the piano is superimposed on the singers, who had a prominent place in this kind of iconography.

By means of the above-mentioned documentary by Yan Ting Yuen it is possible also to come to a clear understanding of the way in which the music of the traditional Chinese opera was "strangled" in favour of the interests of the Revolution, and the way in which all those active in the process of musical creation (musicians, conductors, singers) were strongly oppressed and punished when they dared to take up any position contrary to that of Jiang Qing. This was the case with the conductor Huang Xiao Tong. At seventeen he began to attend the Shanghai Conservatoire, later studying in the former USSR, at the Tchaikovsky Conservatoire in Moscow. On returning to China, he excelled in the training of orchestras and conductors ${ }^{67}$ leaving a European musical legacy well established in China. Concerning the Cultural Revolution and the yangbanxi he says:

The music was lovely ... especially the folk music. It was taken from the Beijing Opera. So, it was very popular with the general public. But the content was strongly politically colourful. The depth and the diversity of the music were restricted by the political aspect. Art should be free and should in no way be hindered. Art has wings and should be able to fly anywhere. There should be no restrictions, no obstacles. So, we didn't agree with it at all. Not at all. I was not afraid, and I did object to the political limitations imposed. That's why I was locked up in a stable for quite some time. If your opinion differed from that of Jiang Qing, Madame Mao, you were arrested. And you were locked up to make you change your mind. You couldn't leave until your opinion had changed. ${ }^{68}$

On listening to the music of the yangbanxi it is impossible not to note similarities with the music of the former USSR. In mainland China during the 1950s musical education was influenced by the Soviet model. The Zhdanov Doctrine of 1948, which condemned musical modernism as formalist, determined the educational style not just in the Tchaikovsky Conservatoire in Moscow, where many Chinese musicians were trained, but also in China's own conservatories. ${ }^{69}$ The pianist Yin Chengzong (mentioned above in connection with the piano version of the Red Lantern) also studied at the Leningrad Conservatoire ${ }^{70}$ in 1960, becoming a member, in 1965, of the Central Orchestra of China as a soloist.

67. Students of Huang Xiao Tong included the conductors Long Yu, Muhai Tang, Guoyong Zhang, Chen Xieyang, Xu Zhong and Lin Yousheng.

68. Transcription of an excerpt from the documentary by Yan Ting Yuen.

69. Mittler, A Continuous Revolution, 45.

70. Presently known as the Rimsky-Korsakov State Conservatoire of St. Petersburg. 
The relationship with Western music is a duality sometimes difficult to understand. On the one hand, hostility and prohibitions on the teaching and performance of music from the Western tradition. On the other, permissiveness and its use in cases considered to be in the service of Mao Zedong's regime. This was what happened with the piano-accompanied version of the Red Lantern and the symphonic version of Sachiapang.

\section{Conclusion}

Jiang Qing, the first "heroine-villain" of the Chinese Cultural Revolution, constructed in her image the heroines of the opera stage; from the "oppressed" and "ghosts" of the old regime, they became fighters of the proletariat. Jiang traced for women a leading position on the stage based on her own existence and life story.

The "model opera" was at the service of her political objectives, showing China to have a strong intelligence, political astuteness and an international strategy. The depth and diversity of the music were, at the time, restricted and subjugated by political aspects and creative freedom completely oppressed. Jiang severely punished all those dared to show some opposition to her cultural model and her model of thought (musicians, singers, composers, playwrights, etc.). ${ }^{71}$

Jiang Qing, who oscillated between geniality and villainy, controlled an entire nation through her "eight grotesque model operas," the "operas of heroines" in which woman took on the central role.

She [Jiang Ching] created eight grotesque model operas. The operas of heroines. The operas of her deep emotions. She told him [Mao Zedong] that they would secure his red kingdom. She made the population of billions watch the same operas for ten years. She made the children recite the lines and sing the arias. She allowed them to watch nothing but her operas. She tamed them, she had to, and they became her pets. Because she represented Mao ... she was almost voted as the Chairman of the Communist Party of China. The masses, the millions of fans, worshiped her opera heroines. And her. She had become their religion. The masses started to say, Long live Comrade Jiang Ching! In their morning ceremony before working. She was the morning star hanging over the rim of the nation's world. ${ }^{72}$ 1999).

71. See Ross Terril, Madame Mao: The White-Boned Demon (California: Stanford University Press, 72. Min, Red Azalea, 292. 
The attempt to erase (or, at least lose the memory) from the Chinese collective memory the figure of Jiang Qing and her yangbanxi failed, because they reverberated in the generations that came afterwards, until they became the adults of today. Though she was judged and condemned ${ }^{73}$ and practically banished from contemporary Chinese history, her legacy would continue in the collective memory of those who knew the original productions.

Though the propaganda imperative is obvious, and though those who were her victims knew that the yangbanxi were "masked" by a false idea of freedom, the Chinese still retain affection for these works, sing their songs and make modern remasterizations. The Cultural Revolution moulded opera to levels that approximated those of the Western musical tradition, creating an art form that mixed both traditions. ${ }^{74}$ It is recognized as such by the Chinese people, by international musicians and musicologists. Because, propaganda or not, the yangbanxi were and continue to be significant points in the worldwide history of music. Mittler also refers:

Reverberations of the model works can be found almost everywhere in contemporary Chinese culture - from the fine arts to the spoken theatre, from literature to music. They have left their mark on China's recent pop and rock music, and even its burgeoning jazz scene, and they have influenced China's classical art music traditions as well. ${ }^{75}$

Thus, the "heroine-villain," Jiang Qing, won. She triumphed on the stage of life and the stage of the world. She gained a place in a time and in history that wishes to push her into the background, remembering only the "dominant male hero," Mao Zedong. ${ }^{76}$

73. Jiang Qing was imprisoned in 1976, tried and condemned to death. However, her sentence would be altered to life imprisonment in 1983. When she was freed in order to receive oncological treatment in 1991, she committed suicide.

74. See also Liu Kang, "Popular Culture and the Culture of the Masses in Contemporary China," Postmodernism and China 24/3 (Autumn 1997), 99-122; and Lu Xing, Rethoric of the Cultural Revolution: the Impact on Chinese Thought, Culture, and Communication (Columbia: University of South Carolina Press, 2004).

75. Mittler, A Continuous Revolution, 50.

76. This work was funded by national funds through the FCT (Fundação para a Ciência e a Tecnologia, I.P.), under the Norma Transitória (DL 57/2016/CP1453/CT0086). 